\title{
Translating Overactive Bladder Questionnaires in Moroccan Arabic Dialect
}

\section{Ahmed Amine El Oumri1,2*, Ossama El Hilali3 ${ }^{3}$ Mohamed Asebane4, Younes El Anbari5, Saloua Khalfaoui ${ }^{6}$}

${ }^{1}$ Service de MPR, CHU Mohamed VI, Oujda, Maroc

${ }^{2}$ Faculté de Médecine et de pharmacie d'Oujda, Université Mohamed premier Oujda, Oujda, Morocco

${ }^{3}$ Service de MPR, CHP Hay mohamadi Casablanca, Casablanca, Morocco

${ }^{4}$ Service d'Urologie, CHP Hoceima, Hoceima, Morocco

${ }^{5}$ Service de MPR, CHP Benimellal, Benimellal, Morocco

${ }^{6}$ Service de MPR, HMVIM, Rabat, Morocco

Email: ^aa.eloumri@gmail.com

How to cite this paper: El Oumri, A.A., El Hilali, O., Asebane, M., El Anbari, Y. and Khalfaoui, S. (2018) Translating Overactive Bladder Questionnaires in Moroccan Arabic Dialect. Open Access Library Journal, 5: e4216.

https://doi.org/10.4236/oalib.1104216

Received: November 29, 2017

Accepted: January 12, 2018

Published: January 15, 2018

Copyright ( 2018 by authors and Open Access Library Inc.

This work is licensed under the Creative Commons Attribution International License (CC BY 4.0).

http://creativecommons.org/licenses/by/4.0/

\begin{abstract}
Objective: linguistic validation in Moroccan Arabic dialect of overactive bladder questionnaires $\mathrm{OAB}-\mathrm{q}$, developed and validated initially in English. Materials and Methods: Questionnaire OAB-q Moroccan Arabic dialect version was obtained after a double translation (English-Arabic), a back translation (Arabic-English), a journal of translations by three experts, comprehension tests and cultural adaptation on a sample of 10 patients with overactive bladder syndrome. Results: The OAB-q in two parts. The first eight items had assessed the discomfort associated with symptoms of overactive bladder (urinary frequency day and night, urgency and urge incontinence). The second included 25 items and measured the impact on quality of life (coping behavior, embarrassment, sleep, social interactions). The conceptual and cultural adaptation was performed on a sample of 10 patients ( 5 with multiple sclerosis, 5 spinal cord injuries), the average age is $42,4+/-7.6$, the sex ratio is 1 . Discussion and Conclusion: OAB-q has been validated in men and women with symptoms of overactive bladder with or without incontinence (a neurological or not). Internal consistency and discriminative construct validity were demonstrated. It has been well validated in patients with multiple sclerosis and spinal cord injury. The linguistic validation Moroccan Arabic dialect is the initial step pending a psychometric validation with larger number of patients.
\end{abstract}

\section{Subject Areas}

Urology 


\section{Keywords}

Overactive Bladder Questionnaires, Quality of Life, OAB q, Moroccan Arabic Dialect

\section{Introduction}

Urinary disorders are well known as a cause to change the daily life of patients. They are responsible for sleep disorders, depression, anxiety, low self-esteem and social retirement [1] [2] [3]. In addition, it is also known that there is a variable relationship between the urinary symptoms, whatever its severity, and the discomfort for which they are responsible. In fact, the clinical measures of symptoms' severity are little correlated to the subjective perception of the symptoms lived daily by the patient [4].

Otherwise, patients and clinicians differ in their perceptions regarding the resounding of symptoms on the quality of life [5]. This emphasizes the idea that there should be a patient self-assessment in chronic diseases. Many works have shown that there are little correlations between the resounding of urinary incontinence in the daily life of a patient and the symptomatic, clinical and paraclinical evaluations used to evaluate urinary disorders (voiding diary, pad test, scale of symptoms, urodynamic parameters) [6] [7] [8] [9] [10]. The symptomatic evaluation of the urinary disorders through the voiding diary shows the reality of symptoms. The pad test measures the leakage frequency. The scales of symptoms quantify the disorders. Urodynamic parameters bring a physiopathological reflection and an understanding concerning the risk in the upper urinary tract. Nevertheless, these measures don't reflect the resounding lived by the patient. They are only a guide to a therapeutic management, and don't let us take into consideration the patient perception.

That's why the Second International Consultation about Incontinence recommends including questionnaires about the quality of life specific for urinary disorders in every clinical trial [11]. Overactive Bladder Questionnaire (OAB-q) is a questionnaire about symptoms and quality of life, initially tested and validated in English Language, for men and women who present an overactive bladder syndrome, with or without urinary incontinence (Neurogenic or not) [12].

The aim of the study is to validate this questionnaire to the Moroccan dialect language so that it can be used by practitioners for the Moroccan population. We will proceed to a forward translation, a backward translation, a clinician's review and a cognitive debriefing.

\section{Materials and Methods}

The process followed for linguistic validation of the questionnaire in Moroccan Arabic responds to a well-defined international methodology [13]. It is also 
partly inspired from the linguistic validation used in short French versions of symptoms' questionnaires (PFDI-20) and the quality of life questionnaires (PFIQ-7) for patients who present a pelvic floor disorder [14].

The objective of this work is to have a translation of the original questionnaire, which would be both conceptually equivalent and easily understandable by Moroccan patients.

\subsection{Forward Translation}

English-Moroccan Arabic for overactive bladder questionnaire (OAB-q).

The "OAB-q" has been independently translated by two professional translators who are bilingual; their mother tongue is Arabic Language, and master well English Language. A reconciled version was produced after assimilating and comparing their two translations (This gives birth to the Arabic version No. 1).

\subsection{Backward Translation}

A back translation of the reconciled version into English has been carried out by two professional translators, whose the mother tongue is the source language and speak fluently the target language.

This new English version of "OAB-q" was compared with the original one. Few differences were identified and analyzed by a Moroccan expert in scales of quality of life associated with health (QVLS).

This expert will be consulted throughout the validation process. Therefore, changes were brought to the Arabic version of OAB-q (overactive bladder questionnaire) (giving birth to the Arabic version No. 2).

\subsection{Review of Clinicians: Clinician's Review}

Two clinicians, experts in management of neurogenic bladder, have been designated to review and revise the questionnaire and give their opinion concerning the used terms.

Clinicians commented on a few items, these remarks were taken into consideration.

A consultation between clinicians on the final version was made.

\subsection{Cognitive Debriefing}

The new version of translation was reviewed by our two clinicians and after that tested through a sample of ten (10) patients suffering from neurological diseases: five are spinal cord injury patients, and five are sclerosed in plate patients. All of them present an overactive bladder syndrome (urge incontinence, micturition urgency, pollakiuria).

The objective of the test is to determine whether the wording (formulations) used is clear, acceptable and suitable as well as to reveal eventual unexpected semantic errors.

Some changes, suggested by the patients, have been adopted provided that 
they don't alter the concept of the original questionnaires. Hence, a third version is then produced, after being reviewed by our expert. This version is the final Arabic version of "OAB-q".

\section{Results}

We proceeded to a random choice of ten patients for doing the cognitive debriefing of OAB-q. Five of them were sclerosed in plate patients; whereas, the other five were spinal cord injury patients. The average age was 42.4 years more are less (+/-) 7.6; the sex ratio was of 1 .

The five sclerosed in plate patients had an Expanded Disability Status Scale (EDSS) mean of 7, and the spinal cord injury patients had paraplegia (back injury level for four patients and a lumbar level lesion (L2) for one patient). In what concerns their level of education: $60 \%$ of the patients had a primary level, $30 \%$ had a secondary level and $10 \%$ had a university level. The average filling time picked up was 10, 4 minutes (6 to 16).

Overactive bladder questionnaire (OAB-q): a questionnaire of symptoms and the quality of life related to overactive bladder syndrome (Annex 1).

"OAB-q" contains two parts which have thirty three (33) items. The first part has eight items and evaluates the discomfort associated with overactive bladder symptoms (daytime and nighttime urinary frequency (Pollakiuria), urge incontinence). The second part has twenty five (25) items and measures the impact on the quality of life: coping (items: $9,11,16,21,22,26,32,33$ ), discomfort (items: $12,13,14,19,23,25,29$ ), sleep (items: 10, 15, 17, 24, 30), and social interactions (items: 18, 20, 27, 28, 31).

The questionnaire had been validated by men and women presenting overactive bladder symptoms with or without incontinence (neurogenic or not). Its internal consistency as well as its discriminative construct validity had been proven [12], just as its sensitivity to changes [15].

We introduced a short version, holding six items associated with overactive bladder symptoms, and thirteen items measuring the impact on the quality of life.

Every item has a six points response scale ranging from 1 to 6 , indicating the discomfort degree (pitch, grade) caused by overactive bladder symptoms during the last four weeks " 1 " means absence of discomfort and " 6 " means maximum discomfort. The listing of items designed for the impact of urinary disorders on the quality of life associated with health is also ranging from 1 to 6 , where " 6 " indicates the very severe impact during the last four weeks preceding the test.

The measurement of scores is divided into two parts: first, the measure related to the Average score of symptoms' severity and second, the measure related to the Average score of the quality of life associated with health. This measurement is made on the basis of a percentage calculated after the deduction of the total score of the lowest possible current score of the patient. This total score is di- 
vided by a possible score of rows.

\section{Discussion}

The questionnaires concerning the quality of life and which are specific to the urinary disorders are generally developed to evaluate a particular symptoms found in male or female patients. Therefore, the majority of the questionnaires are specific to one sex. These questionnaires target mainly the incontinence in women case; whereas, in men case, they focus on obstructive symptoms associated with benign prostatic hyperplasia [16].

The questionnaires, developed for the two sexes, measure mainly the impact of urge incontinence (OAB-q and Qualiveen), and for certain of them, the impact of associated symptoms related to overactive bladder (OAB-q). A rigorous translation is essential to produce a questionnaire about the quality of life associated with health and that could be used in new languages and cultures for which it is destined.

International experts in the quality of life associated with health have set recommendations concerning translation methodologies, adaptation and validation of questionnaires in different languages and cultures [17] [18] [19] [20]. Investigators and researchers usually develop a questionnaire of the quality of life associated with health in English language, and then translations with cultural adaptations in other languages are achieved or done.

In our study, the translation of symptoms that use adjectives such as "uncomfortable", "uncontrollable", "anxiety", and "worry" proved to be difficult in our Moroccan context. Cultural adaptation has also been made with respect to item 21 which deals with the concept of travel.

We have to note that we had taken time to explain to patients the meaning and signification of some terms before they began to fill their questionnaires. The time of explanation was estimated between five to fifteen minutes.

Knowing that the majority of the patients are illiterate, the questionnaire is filled with the help of a physician (Medical Doctor) or a literate attendant, indicating the patient response; this will be a bias in achieving a possible psychometric validation.

The "OAB-q" is now the only measurement specifically designed to evaluate the quality of life for continent or incontinent patients with overactive bladder $(\mathrm{OAB})$. The "OAB-q" is developed to evaluate the discomfort extent of the patient, which is caused by the overactive bladder (OAB) symptoms, and the impact of these symptoms on the quality of life of the patients. This measure consists, as we have already shown ,on eight items of measurement of symptoms' severity and a scale of twenty five items evaluating four domains of the quality of life (adaptation, worry, sleep, and social interaction) [12].

The "OAB-q" is also available in an abbreviated form (OAB-q SF) consisting of six items of severity symptoms and thirteen ones of quality of life associated with heath [21]. The "OAB-q" and "OAB-q SF" have been incorporated in the 
international consulting incontinence questionnaire on the overactive bladder [22].

The "OAB-q" has been validated on continent and incontinent patients having an overactive bladder [12]. In an evaluation study concerning 990 men and women suffering from overactive bladder, The "OAB-q" showed good construct validity [12]. The psychometric validation of the thirty three items has been done [12]. The "OAB-q" and the non-specific scale of quality of life SF-36 have been filled by the participants from two sources: the first source is a sample concerning the positive screening of the overactive bladder in a random way based on phone survey $(\mathrm{n}=254)$, and the second source is a clinical study on the treatment of patients and which objective is to look for overactive bladder symptoms (of evaluation basis) $(n=736)$. The psychometric evaluation is done to evaluate the reliability and the validity of the questionnaires. Sixty four percent of the sample was women having as an average Age 58.5. Meaningful differences were noticed among all the patients of the groups in all sub-scales of OAB-q ( $p<0.0001)$, except sleep sub-scale and the impact of overactive bladder sub-scale which were alike at continent and incontinent patients, but significantly less than normal participants $(\mathrm{p}<0.0001)$. The internal consistency was high with the coefficient "Cronbach's alpha" ranging from 0.86 to 0.94 [12].

In a study of 47 patients suffering from overactive bladder, the "OAB-q" showed good reliability concerning test-retest (reproducibility) [23]. In another study in the same field, 865 patients were treated with tolterodine; here, the "OAB-q" proved to be sensitive to the change associated to the treatment, with statistically significant correlations [24]. The "OAB-q" was used to give a quantitative evaluation of nocturia impact on the quality of life associated with health and sleep, which is a discriminatory point for patients who suffer from different degrees of nocturia [25]. Besides, the "OAB-q" was used to survey and examine the impact of urge incontinence, incontinence with effort, and mixed incontinence on the quality of life associated with health [26].

The "OAB-q" is more sensitive than the generic instruments in detecting differences between patients suffering from different types of incontinence. In a recent post hoc analysis, two clinical trials using tolterodine, have been used to show that the distribution of all "OAB-q" sub-scales is of 10 points [27]. In the clinical trials, the researchers need instruments which are concise and easily filled by the patients, but which could give useful information so as to have meaningful and explainable results of the treatment. A series of questionnaires are available to evaluate the severity and the incontinence impact; however, few of them have been designed and validated specifically for overactive bladder. Now, the measure which is widely validated for overactive bladder is the "OAB-q" [28], and it is developed in American English and translated to over than 40 languages [29].

After a series of initial validations involving 14 languages [30]: Danish, English (Canada), French (Canada, France), Italian (Switzerland), German (Switzer- 
land), Korean, Norwegian, Polish, Portuguese (Brazil), Romanian, Swedish, and Turkish, the linguistic validations have been carried out following a rigorous method in order to assure a conceptual equivalence between the original and the translations. In every country, a specialist monitors the process, which holds six steps: two translations, a comparison and reconciling of translation, back translation, a comparison of the source questionnaire and the back translation, review by an urologist or a gynecologist, and using a cognitive debriefing of the patients. The translation of symptoms using adjectives such as "uncomfortable", "suddenly", "accidental", "uncontrollable", has proved to be a challenge. Subtle differences in the meaning of symptomatic elements increased the difficulties of finding equivalent words. The terms "wish", "desire", "urinate", "switch", "sleepy", and "evacuation tract" are not used literally and are replaced by familiar expressions. Subsequently, the linguistic versions of "OAB-q" in: Danish, German, Polish, Swedish, and Turkish languages gained a psychometric validation, based on psychometric characteristics, especially the reliability of internal consistency, the construct validity, and the reproducibility.

This questionnaire had been translated into different languages (more than fourteen languages), making it one of the most used questionnaires in the world; our contribution is to develop a tool that will be used by Moroccan practitioners.

We have chosen 10 patients for the linguistic validation of this questionnaire, this number will not be able to affect this version of translation, but a psychometric study with a larger number of patients is to be expected.

\section{Conclusions}

The "OAB-q" is a self-administered questionnaire, validated initially in English language, prepared for patients who suffer from overactive bladder symptoms, with Neurogenic origin or not. This questionnaire had been translated into different languages (more than fourteen languages), making it one of the most used questionnaires in the world.

This questionnaire will help us to carry out academic research in the management of over active bladder in Morocco, and also to meet the needs of patients suffering from such a symptom.

The Arabic version of "OAB-q" is one of the first measurement instruments of the quality of life, validated linguistically in Moroccan Arabic. It is developed especially for spinal cord injury and sclerosed in plate patients who have vesico-sphincter disorders.

This linguistic validation is only the first step, expecting to achieve a further psychometric validation.

\section{References}

[1] Abrams, P., Kelleher, C.J., Kerr, L.A. and Rogers, R.G. (2000) Overactive Bladder Significantly Affects Quality of Life. American Journal of Manage Care, 6, S580S590. 
[2] Brown, J.S., Mc Ghan, W.F. and Chokroverty, S. (2000) Comorbidities Associated with Overactive Bladder. American Journal of Manage Care, 6, S574-S579.

[3] Wagner, T.H., Hu, T.W., Bentkover, J., LeBlanc, K., Stewart, W., Corey, R., Zhou, Z. and Hunt, T. (2002) Health Related Consequences of Overactive Bladder. American Journal of Manage Care, 8, S598-S607.

[4] Litwin, M.S., Hays, R.D., Fink, A., Ganz, P.A., Leake, B., Leach, G.E. and Brook, R.H. (1995) Quality-of-Life Outcomes in Men Treated for Localized Prostate Cancer. JAMA, 273, 129-135. https://doi.org/10.1001/jama.1995.03520260051032

[5] Litwin, M.S., Lubeck, D.P., Henning, J.M. and Carroll, P.R. (1998) Differences in Urologist and Patient Assessments of Health Related Quality of Life in Men with Prostate Cancer: Results of the CaPSURE Database. Journal of Urology, 159, 1988 1992. https://doi.org/10.1016/S0022-5347(01)63222-1

[6] Harvey, M.A., Kristjansson, B., Griffith, D. and Versi, E. (2001) The Incontinence Impact Questionnaire and the Urogenital Distress Inventory: A Revisit of Their Validity in Women without a Urodynamic Diagnosis. American Journal of Obstetrics Gynecology, 185, 25-30. https://doi.org/10.1067/mob.2001.116369

[7] Jackson, S. (1997) The Patient with an Overactive Bladder-Symptoms and Qualityof-Life Issues. Urology, 50, 18-22. https://doi.org/10.1016/S0090-4295(97)00580-3

[8] Ryhammer, A.M., Laurberg, S., Djurhuus, J.C. and Hermann, A.P. (1998) No Relationship between Subjective Assessment of Urinary Incontinence and Padtest Weight Gain in a Random Population Sample of Menopausal Women. Journal of Urology, 159, 800-803. ttps://doi.org/10.1016/S0022-5347(01)63735-2

[9] Schumaker, S., Wyman, J.F., Uebersax, J.S., Mc Clish, D. and Fantl, J.A. (1994) Health Related Quality of Life Measures for Women with Urinary Incontinence: The Incontinence Impact Questionnaire and the Urogenital Distress Inventory. Quality of Life Research, 3, 291-306. https://doi.org/10.1007/BF00451721

[10] Wyman, J.F., Harkins, S.W., Choi, S.C., Taylor, J.R. and Fantl, J.A. (1987) Psychosocial Impact of Urinary Incontinence in Women. Obstetrics and Gynecology, 70, 378-381.

[11] Donovan, J.L., Badia, X., Corcos, J., Gotoh, M., Kelleher, C.J. and Naughton, M. (2002) Symptom and Quality of Life Assessment. In: Abrams, P., Cardozo, L., Khoury, S. and Wein, A., Eds., Incontinence: Second International Consultation Proceedings. Health Publication, Plymouth, 267-316.

[12] Coyne, K., Revicki, D., Hunt, T., Corey, R., Stewart, W., Bentkover, J., Kurth, H. and Abrams, P. (2002) Psychometric Validation of an Overactive Bladder Symptom and Health-Related Quality of Life Questionnaire: The OAB-q. Quality of Life Research, 11, 563-574. https://doi.org/10.1023/A:1016370925601

[13] Acquadro, C., Jambon, B., Ellis, D. and Marquis, P. (1996) Language and Translation Issues. In: Spilker, B., Ed., Quality of Life and Pharmaco Economics in Clinical Trials, Lippincott-Raven Publishers, Philadelphia, 575-585.

[14] de Tayrac, R., Deval, B., Fernandez, H. and Mares, P. (2007) Validation linguistique en francais des versions courtes des questionnaires de symptômes (PFDI-20) et de qualité de vie (PFIQ-7) chez les patientes présentant un trouble de la statique pelvienne. Journal de Gynécologie Obstétrique et Biologie de la Reproduction, 36, 738-748. https://doi.org/10.1016/j.jgyn.2007.08.002

[15] Coyne, K.S., Matza, L.S., Thompson, C., Jumadilova, Z. and Bavendam, T. (2007) The Responsiveness of the OAB-q among OAB Patient Subgroups. Neurourology Urodynamics, 26, 196-203. https://doi.org/10.1002/nau.20342 
[16] Bonniaud, V., Raibaut, P., Guyatt, G., Amarenco, G. and Parratte, B. (2005) Symptom and Quality of Life Assessment in Urinary Disorders. Annales de Réadaptation et de Médecine Physique, 48, 392-403. https://doi.org/10.1016/j.annrmp.2005.02.011

[17] Aaronson, N.K., Acquadro, C., Alonso, J., Apolone, G., Bucquet, D., Bullinger, M., et al. (1992) International Quality of Life Assessment (IQOLA Project). Quality of Life Research, 1, 349-351. https://doi.org/10.1007/BF00434949

[18] Cook, D.J., Guyatt, G.H., Juniper, E., Griffith, L., McIlroy, W., Willan, A., et al. (1993) Interviewer vs. Self Administered Questionnaires in Developing a Diseasespecific, Health-Related Quality of Life Instrument for Asthma. Journal of Clinical Epidemiology, 46, 529-534. https://doi.org/10.1016/0895-4356(93)90125-K

[19] Guillemin, F., Bombardier, C. and Beaton, D. (1993) Cross-Cultural Adaptation of Health-Related Quality of Life Measures: Literature Review and Proposed Guidelines. Journal of Clinical Epidemiology, 46, 1417-1432. https://doi.org/10.1016/0895-4356(93)90142-N

[20] Ware Jr., J.E. (1987) Standards for Validating Health Measures: Definition and Content. Journal of Chronic Diseases, 40, 473-480. https://doi.org/10.1016/0021-9681(87)90003-8

[21] Coyne, K.S., Lai, J.-S., Zycyzynski, T., et al. (2004) An Overactive Bladder Symptom and Quality-of-Life Short Form: Development of the Overactive Bladder Questionnaire Short Form (OAB-q SF). 34th Joint Meeting of the International Continence Society and the International Urogynecological Association, 23-27 August 2004, Paris.

[22] Abrams, P., Avery, K., Zyczynski, T., et al. (2004) Measuring Patient Outcomes in OAB: The OAB-q, OAB-q SF, OAB Screener and ICIQ-OAB [abstract]. Neurourology Urodynamics, 23, 399.

[23] Matza, L.S., Thompson, C.L., Krasnow, J., et al. (2005) Test-Retest Reliability of Four Questionnaires for Patients with Overactive Bladder: The Overactive Bladder Questionnaire (OAB-q), Patient Perception of Bladder Condition (PPBC), Urgency Questionnaire (UQ), and the Primary OAB Symptom Questionnaire (POSQ). Neurourology Urodynamics, 24, 215-225. https://doi.org/10.1002/nau.20110

[24] Coyne, K.S., Matza, L.S. and Thompson, C.L. (2005) The Responsiveness of the Overactive Bladder Questionnaire (OAB-q). Quality of Life Research, 14, 849-855. https://doi.org/10.1007/s11136-004-0706-1

[25] Coyne, K.S., Zhou, Z., Bhattacharyya, S.K., et al. (2003) The Prevalence of Nocturia and Its Effect on Health Related Quality of Life and Sleep in a Community Sample in the USA. BJU International, 92, 948-954. https://doi.org/10.1111/j.1464-410X.2003.04527.x

[26] Coyne, K.S., Zhou, Z., Thompson, C., et al. (2003) The Impact on Health-Related Quality of Life of Stress, Urge and Mixed Urinary Incontinence. BJU International, 92, 731-735. https://doi.org/10.1046/j.1464-410X.2003.04463.x

[27] Coyne, K., Matza, L., Thompson, C., et al. (2006) Determining the Importance of Change in the OABq. Journal of Urology, 176, 627-632. https://doi.org/10.1016/j.juro.2006.03.088

[28] Coyne, K.S., Tubaro, A., Brubaker, L., et al. (2006) Development and Validation of Patient-Reported Outcomes Measures for Overactive Bladder: A Review of Concepts. Urology, 68, 9-16. https://doi.org/10.1016/j.urology.2006.05.042

[29] Coyne, K.S., Margolis, M.K., Thompson, C., et al. (2008) Psychometric Equivalence of the OAB-q in Danish, German, Polish, Swedish, and Turkish. Value in Health, 7, 
1096-1101. https://doi.org/10.1111/j.1524-4733.2008.00346.x

[30] Acquadroa, C., Kopp, Z., Coyne, K.S., et al. (2006) Translating Overactive Bladder Questionnaires in 14 Languages. Urology, 67, 536-540.

https://doi.org/10.1016/j.urology.2005.09.035 


\section{Annexe I: Overactive Bladder Questionnaire in Moroccan Arabic Dialect}

الغرض من هاد الأسئلة هو نعرفو شحال كثقلقك أعر اض النبولة ف 4 ديال الأسابيع الأخيرة. رجاءوا دير علامة ل أو x اللي كتعبر

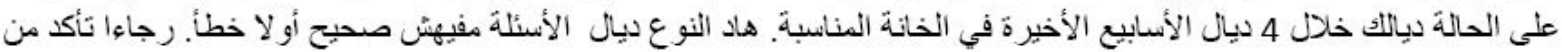
الأجوبة على كل سؤال.

\begin{tabular}{|c|c|c|c|c|c|c|}
\hline 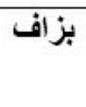 & بقدر كبير & بثكل باين & ما بين و & شوية & نهائيا & ... فهاد 4 الأسابيع، شحال عانيتي من \\
\hline$\square_{6}$ & $\square$ & $\square_{4}$ & $\square_{3}$ & $\square$ & $\square$ & 1- كترت البول النهار كامل \\
\hline$\square_{6}$ & $\underset{5}{\square}$ & $\square$ & $\underset{3}{\square}$ & $\square_{2}$ & $\square_{1}$ & 2- الر غبة فالبول بسر عة و بإلحاح \\
\hline$\square_{6}$ & $\square$ & $\square$ & $\square_{3}$ & $\square$ & $\square_{1}^{\square}$ & 3- الر غبة فالبول بلا متعلم \\
\hline$\square_{6}$ & $\frac{\square}{5}$ & $\square$ & $\square$ & $\frac{\square}{2}$ & $\underset{1}{\square}$ & 4- تبول قطر ات بلا شعور \\
\hline${ }_{6}^{\square}$ & $\square$ & $\square$ & $\square$ & $\square_{2}$ & $\underset{1}{\square}$ & 5- البول بالليل \\
\hline$\square_{6}$ & $\frac{\square}{5}$ & $\square$ & $\square$ & $\underset{2}{\square}$ & $\frac{\square}{1}$ & 6- الفياق بالليل بسبب البول \\
\hline$\square_{6}$ & $\square$ & $\square$ & $\square_{3}$ & $\square$ & $\underset{1}{\square}$ & 7- رغبة فالبول منقمدرش توقةها \\
\hline$\frac{\square}{6}$ & $\frac{\square}{5}$ & $\frac{\square}{4}$ & $\frac{\square}{3}$ & $\frac{\square}{2}$ & $\frac{\square}{1}$ & 8- الر غبة الكبيرةً في البول واخا تتبول \\
\hline
\end{tabular}




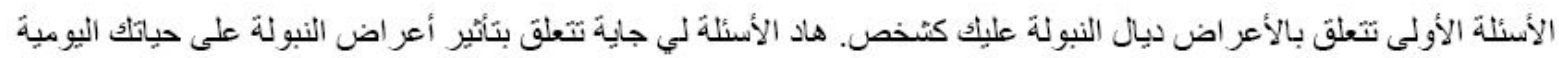

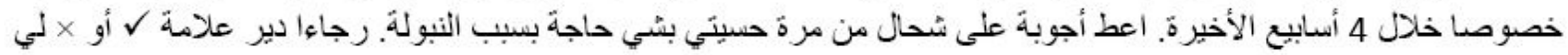

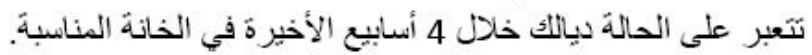

\begin{tabular}{|c|c|c|c|c|c|c|}
\hline دائما & اغلب الأوقات & بزاف ديال & مرة مرة & المرات & ولا مرة & 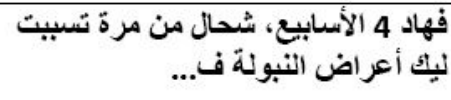 \\
\hline$\square$ & $\square$ & $\square$ & $\square$ & $\square$ & $\square$ & 9- انكا خصك تفكر قبل ما تمنسي لأي \\
\hline 6 & 5 & 4 & 3 & 2 & 1 & بلاصة \\
\hline$\square$ & $\square$ & $\square$ & $\square$ & $\square$ & $\square$ & 10- الإحساس بالنعاس وسط النهار \\
\hline 6 & 5 & 4 & 3 & 2 & 1 & \\
\hline$\square$ & $\square$ & $\square$ & $\square$ & $\square$ & $\square$ & 11-التقلاب على بيت الماء فثبي مكان \\
\hline 6 & 5 & 4 & 3 & 2 & 1 & عمومي \\
\hline$\square$ & $\square$ & $\square$ & $\square$ & $\square$ & $\square$ & 12 12 التقليقةًة \\
\hline 6 & 5 & 4 & 3 & 2 & 1 & \\
\hline$\square$ & $\square$ & $\square$ & $\square$ & $\square$ & $\square$ & 13- 13- الخلعة \\
\hline 6 & 5 & 4 & 3 & 2 & 1 & \\
\hline$\square$ & $\square$ & $\square$ & $\square$ & $\square$ & $\square$ & 14- الإحساس باللي فيك شي حاجةُ مشي \\
\hline 6 & 5 & 4 & 3 & 2 & 1 & حتال تما \\
\hline
\end{tabular}

\begin{tabular}{|c|c|c|c|c|c|c|}
\hline$\square$ & $\square$ & $\square$ & $\square$ & $\square$ & $\square$ & 15- أنك منتشعس مرتاح بالليل \\
\hline 6 & 5 & 4 & 3 & & 1 & \\
\hline$\square_{6}^{\square}$ & $\underset{5}{\square}$ & $\underset{4}{\square}$ & $\underset{3}{\square}$ & $\underset{2}{\square}$ & $\square_{1}$ & الر باضة مثّل من الحركة في النهار : بحا \\
\hline
\end{tabular}

\begin{tabular}{|c|c|c|c|c|c|c|}
\hline$\square$ & $\square$ & $\square$ & $\square$ & $\square$ & $\square$ & 17- الفياق في الصباح و أنت ممرتاحش \\
\hline 6 & 5 & 4 & 3 & 2 & 1 & \\
\hline
\end{tabular}

\begin{tabular}{|c|c|c|c|c|c|c|}
\hline$\frac{\square}{6}$ & $\frac{\square}{5}$ & $\frac{\square}{4}$ & $\square_{3}$ & $\frac{\square}{2}$ & $\underset{1}{\square}$ & 18- الخلعة ديال صحابك و عائلتك \\
\hline$\frac{\square}{6}$ & $\underset{5}{\square}$ & $\frac{\square}{4}$ & $\underset{3}{\square}$ & $\frac{\square}{2}$ & $\underset{1}{\square}$ & 19-الهج و الثَقليقة \\
\hline$\square_{6}^{\square}$ & $\square_{5}$ & $\square_{4}$ & $\square_{3}$ & $\underset{2}{\square}$ & $\underset{1}{\square}$ & 20-الخلاس في الدار بزز منك \\
\hline
\end{tabular}

\begin{tabular}{|c|c|c|c|c|c|c|}
\hline$\square$ & $\square$ & $\square$ & $\square$ & $\square$ & $\square$ & 21-أنكلك تقلب تكون ديما قريب من بيت الماء في \\
\hline $\overrightarrow{6}$ & 5 & 4 & 3 & 2 & 1 & 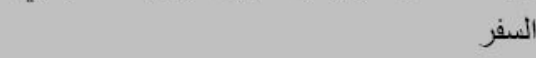 \\
\hline$\square_{6}$ & $\square_{5}$ & $\square_{4}$ & $\square$ & $\square_{2}$ & $\underset{1}{\square}$ & 22-بز ات علئك تبعد على أبي نشاط بحال \\
\hline
\end{tabular}




\begin{tabular}{|c|c|c|c|c|c|c|}
\hline$\frac{\square}{6}$ & 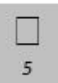 & $\square$ & $\frac{\square}{3}$ & $\frac{\square}{2}$ & $\square$ & 23-الفقلق و الثوتر منين تبقى بز اف في \\
\hline$\frac{\square}{6}$ & $\square$ & $\square$ & $\square$ & $\frac{\square}{2}$ & $\square$ & 24- الفياق و أنت ناعس \\
\hline$\square$ & $\square$ & $\underset{3}{\square}$ & $\square_{3}$ & $\frac{\square}{2}$ & $\frac{\square}{1}$ & 25-القلق بسبب الريحة أو قلة النقة \\
\hline$\square$ & $\underset{5}{\square}$ & $\square$ & $\square$ & $\frac{\square}{2}$ & $\square$ & 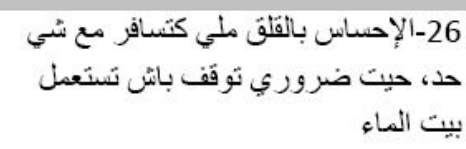 \\
\hline$\frac{\square}{6}$ & $\square$ & $\square$ & $\square$ & $\frac{\square}{2}$ & $\square$ & عائلتأكر أتر ات ليك على العلاقة مع صحابك و \\
\hline$\square$ & $\square$ & $\underset{3}{\square}$ & $\frac{\square}{3}$ & $\frac{\square}{2}$ & $\square$ & 28-نتقصن من الحضور في الحفلات و \\
\hline$\square$ & $\square$ & $\frac{\square}{3}$ & $\frac{\square}{3}$ & $\frac{\square}{2}$ & $\square$ & 29-الحرج \\
\hline$\frac{\square}{6}$ & $\underset{5}{\square}$ & $\frac{\square}{3}$ & $\frac{\square}{3}$ & $\frac{\square}{2}$ & $\square$ & 30-أنك ما تنتعست القذر الكافي \\
\hline$\frac{\square}{6}$ & $\square$ & $\frac{\square}{3}$ & $\frac{\square}{3}$ & $\frac{\square}{2}$ & $\square$ & 31- منشاكل مع مر اتك / راجلك \\
\hline$\frac{\square}{6}$ & $\underset{5}{\square}$ & $\frac{\square}{3}$ & $\frac{\square}{3}$ & $\frac{\square}{2}$ & $\frac{\square}{1}$ & 32- انه خصلك تفكر قبل ما دير أي حاجة \\
\hline$\frac{\square}{6}$ & 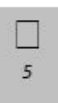 & $\frac{\square}{3}$ & $\frac{\square}{3}$ & $\frac{\square}{2}$ & $\square$ & 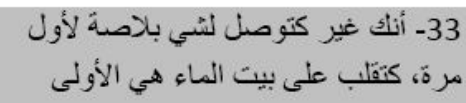 \\
\hline
\end{tabular}

